\title{
EFFECTIVENESS INTERACTIVE DEMONSTRATIONS METHOD ON TeMPerature AND CALOR IN THE TENTH-Grade STUDENTS
}

\author{
Ira Nofita Sari ${ }^{1)}$, Dwi Fajar Saputri ${ }^{2)}$, Helmiyanti ${ }^{3)}$ \\ ${ }^{1)}$ IKIP PGRI Pontianak, Pontianak, Indonesia \\ E-mail: iranofitasari87@gmail.com \\ ${ }^{2)}$ IKIP PGRI Pontianak, Pontianak, Indonesia \\ E-mail: dwifajar24@gmail.com \\ ${ }^{3)}$ IKIP PGRI Pontianak, Pontianak, Indonesia \\ E-mail: helmiyanti11@gmail.com
}

\begin{abstract}
This study aims to determine the effectiveness of the interactive demonstration method on the discussion of temperature and heat in the tenth-grade students of the Segedong Number 1 Senior High School. The method used is a pre-experimental design with the design of the one-shot case study. Data collection techniques used in this study include measurement techniques, direct communication techniques, and indirect communication techniques. The data analysis technique used in this study is quantitative data analysis. Based on data analysis, it is known that the average student learning outcomes reached completeness of $86.67 \%$, and is classified as complete in classical, student learning activities classified as good with a percentage of $67.65 \%$, and student responses are classified as very strong with a percentage of $82.58 \%$, so the interactive demonstration method is effective at the temperature and heat of the material in the tenthgrade students of the Segedong Number 1 Senior High School.
\end{abstract}

Keywords: Interactive Demonstrations Method; Effectiveness; Learning Outcomes; Activity; Responses

\section{INTRODUCTION}

Physics is one of the subjects of natural science and is a science that was born and developed through the steps of observation, the formulation of the problem of preparing hypotheses, testing hypotheses through experiments, conclusions, and the discovery of theories and concepts. According to Trianto (2008), the main purpose of learning physics is knowledge (cognitive). This type of knowledge is a basic knowledge of principles and concepts that are useful for everyday life. Broadly speaking knowledge is the knowledge of facts that exist in nature to be able to understand and deepen further and see the existence of information and order. Physics learning is also expected to provide skills (psychomotor), the ability of scientific attitude (affective), understanding, habits, and appreciation.

In reality, students only memorize concepts and are less able to use concepts if they encounter real-life problems related to concepts. Furthermore, even students are less able to determine the problem and formulate it. Related to students' understanding of teaching materials, there should be many students who have a good level of memorization of the material received so that the learning outcomes are good. This is seen through the results of student learning on physics subjects in the tenth grade of Segedong Number 1 Senior High School students not yet maximal. Evident from the student learning outcomes on the subject of temperature and heat only reached an average of 20.00. While the minimum completeness criteria set by the school is 70.00 . Based on this fact it is clear that there is a very significant gap.

Further investigation of the possible causes of the problem, namely by conducting classroom observations and interviews with teachers and some students. Based on the results of classroom observations, it appears that students are less enthusiastic about participating in ongoing learning. This is evident from the majority of students being passive, listening to the teacher's explanation, not asking questions about concepts that are not understood, only wanting to answer the 
teacher's questions when appointed, and lack of interaction among fellow students during the discussion. In line with the results of the observations, based on the results of interviews with physics subject teachers, it is known that students are less active in learning, students are less interested in the concepts delivered even though they have something to do with the material. Besides, students are also less able to use the concepts obtained in new situations. According to Trianto (2008) students who are less able to connect between what they learn and how knowledge is applied to new situations can influence learning outcomes. After interviewing students, it turns out that one of the causes of low student learning outcomes is due to a lack of students' understanding of the concepts presented, besides students also feel the concept is not valid, so it is less useful. Even though physics material, especially temperature and heat are materials that are close to the daily lives of students. According to Trianto (2009), the subject matter will add meaning if students learn the subject matter presented through the context of their lives, and find meaning in the learning process, so that learning will become more meaningful and enjoyable.

Based on the explanation above, a direct learning method is needed that connects material concepts with real experiences in everyday life. This method is an interactive demonstration method. The interactive demonstration method is one solution offered so students understand concepts, facts, and principles and facilitate teachers in teaching concepts, facts, and principles. The interactive demonstration method is one of the methods developed by Wenning. Wenning (2005) states that interactive demonstration methods generally contain teacher demonstrations of science experiments or events that are common in everyday life. It is said to be interactive because there are interactions between students and students, as well as students and teachers. Students are allowed to predict how experiments can occur. Through the interactive demonstration, the method will create a classroom where students will become active participants not only passive observation, and responsible for learning. The use of interactive demonstration methods will greatly help teachers to connect the material to real-world situations and motivate students to form a relationship between knowledge and application to everyday life so that it will bring up a positive response and will have an impact on the achievement of student learning outcomes.

The results of Annisa, Karim, and Aminudin (2014) note that student learning outcomes have increased in each learning series after the application of interactive demonstration teaching methods. The profile of student activity on average motoric activity is sufficient, good visual activity, good oral activity. Students also provide a positive response to learning through interactive demonstration methods. Therefore, based on the explanation above, the researcher was interested in knowing the effectiveness of the interactive demonstration method in the temperature and heat of the tenth-grade students of the Segedong Number 1 Senior High School.

\section{MethodOLOGY}

The research method used in this research is the experimental method. The form of research used is pre- experimental designs. This form of research is used because this design is not yet a true experiment. There are still many external variables that contribute to the formation of the dependent variable. The result of the experiment which is the dependent variable is not solely influenced by the independent variable (Sugiyono, 2012).

The research method used in this study is the experimental method. The form of research used is a pre-experimental design. This study uses a type of quantitative research. the research was conducted in the high school number 1 Segedong, Mempawah Regency, West Kalimantan Province. The population in this study were the tenth-grade students of the Segedong Number 1 Senior High School which consisted of two classes namely MIA 1 and MIA 2. Determination of the study sample was conducted by cluster random sampling technique. The requirement for selecting samples with this technique is that the population is homogeneous. Then to find homogeneity data then tested using the Bartlett test. Based on the calculation of the average student learning outcomes in some previous physics material, $\chi 2$ count $=2.30$ and $\chi 2$ table $=$ 3.84 , where $\chi 2$ count $\leq \chi 2$ table, so that the population variance is homogeneous. Next, determining the experimental class is carried out by lottery. Based on the results of the draw, the samples obtained in this study were class X MIA 2.

This research was conducted through three stages, namely introduction, implementation, and end. In the initial stage, observations were made to find problems that occurred in the tenth-grade students of the Segedong Number 1 Senior High School, prepare research instruments, validate instruments, conduct test instruments in the form of tests, and analyze the results of instrument tests. Furthermore, at the implementation stage researched in the experimental class to find out the activities of students during learning takes place through observation sheets of student activities, student responses to the learning methods used through the questionnaire response, and knowing student learning outcomes through posttest. The final stage of this research is analyzing the data that has been obtained and concluding.

Based on the form of research used, the research design is One-Shot Case Study. Data collection techniques used in this study include measurement techniques, direct communication techniques, and indirect communication techniques. The data collection tool used is a test of student learning outcomes in the form of post-test, observation sheet, and questionnaire responses of students to the learning methods used.

Data collection techniques used in this study include measurement techniques, direct communication techniques, and indirect communication techniques. The data collection tools used are (1) test of student learning result in the form of posttest in essay form, (2) observation sheet to know student activity during learning, and (3) questionnaire of student response to learning method used.

Data analysis techniques in quantitative research are ways that are directed to answer the problem formulation or test hypotheses that have been formulated. To answer the first problem about student learning outcomes is to calculate the post-test results statistically by changing the score to a value, looking for the percentage of students who achieve 
completeness which is then compared with the percentage of completeness in classical. The second problem about student learning activities is answered by calculating the activities of all students according to Annisa, Karim, and Aminudin (2014) use the following equation (1).

$$
P=\frac{\text { Student Score }}{\text { Maximum Score }=} \times 100 \%
$$

Furthermore, the value of $\mathrm{P}$ is compared with the interpretation of student learning activities based on Table I.

TABLE I

INTERPRETATION OF STUDENT LEARNING ACTIVITY

\begin{tabular}{ccc}
\hline Number & Percentage & Criteria \\
\hline 1. & $\geq 80 \%$ & Very high \\
2. & $60 \%-79 \%$ & High \\
3. & $40 \%-59 \%$ & Enough \\
4. & $21 \%-39 \%$ & Low \\
5. & $0 \%-20 \%$ & Very low \\
\hline
\end{tabular}

The third problem related to student responses to the interactive demonstration learning method can be known through (2).

$\mathrm{X} \%=\frac{\mathrm{n}}{\mathrm{N}} \times 100 \%$

Referring to "(2)", X is the percentage of student responses, $\mathrm{n}$ is the number of actual scores, and $\mathrm{N}$ is the maximum number of scores. After obtaining X\%, then compared with the criteria of student responses according to Riduan (2010) as in Table II.

TABLE II

CRITERIA FOR STUDENT RESPONSE

\begin{tabular}{ccc}
\hline No. & Range & Criteria \\
\hline 1. & $0 \%-20 \%$ & Very weak \\
2. & $21 \%-40 \%$ & Weak \\
3. & $41 \%-60 \%$ & Enough \\
4. & $61 \%-80 \%$ & Strong \\
5. & $81 \%-100 \%$ & Very strong \\
\hline
\end{tabular}

The general problems regarding the effectiveness of the learning methods used can be answered if the three previous problems, namely learning outcomes, student activities, and student responses have been answered. Learning is said to be effective if: (1) student learning outcomes reach minimum mastery criteria $\geq 70$ and the number of students who complete more than $75 \%$; (2) student activities are classified as active during learning using interactive demonstration methods; and (3) student responses are classified as strong during learning using interactive demonstration methods.

\section{RESULTS AND DISCUSSION}

\section{A. Result}

Based on the result of posttest data analysis, it is Based on the results of the posttest data analysis, it is known that the average student learning outcomes are 85.17. Students who achieve completeness scores as many as 26 students from all students totaling 30 students, or if the percentage then students who achieve completeness are $86.67 \%$. From these data said students complete classically because $\geq 75 \%$ of students achieve completeness.

Student learning activities can be seen from each lesson, namely four times learning by paying attention to several aspects, including (1) paying attention to the teacher's explanation and answering the teacher's question at the perception stage, (2) paying attention to the teacher's explanation and answering the teacher's questions at the motivation stage, (3) paying attention to the teacher's explanation and answering teacher questions during the demonstration stage, (4) discussing with group mates and finding solutions for completion of prediction sheets, (5) asking questions to teachers about unknown things, and (6) giving opinions when concluding. More clearly the percentage of student activity in each meeting can be seen in Fig. 1. Based on Fig. 1, it is known that in each learning for aspects one to six, the average student activity has increased. If all the percentage of student activities are averaged then the activity of students is included in the high category, namely with an average percentage of $67.65 \%$, where the average activity in the first to fourth learning is $56.81 \%, 60.90 \%, 77.59 \%$, and $75.29 \%$.

Student responses to learning methods can be seen from student response questionnaires with 20 statement items using a Likert scale, where the statements are given are related to the use of interactive demonstration teaching methods.

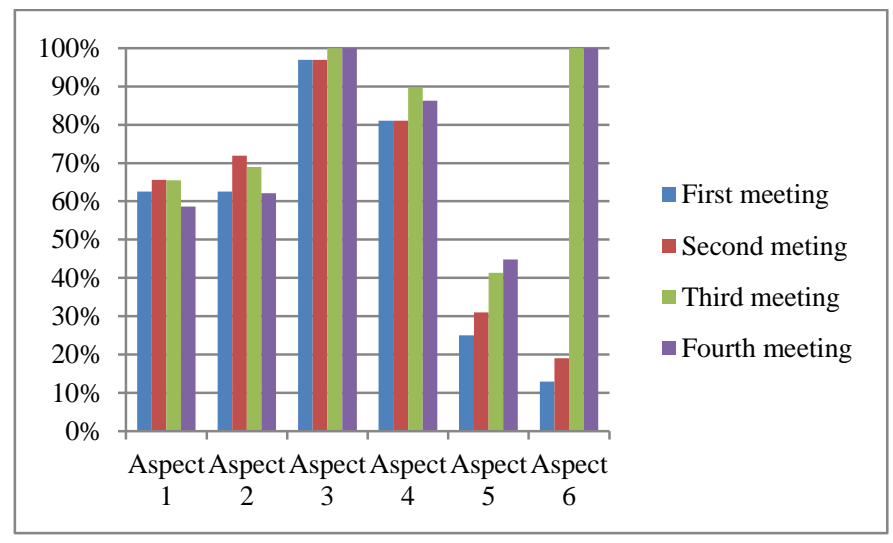

Fig. 1 Summary of Students Activities

Observed aspects include (1) students 'interest in learning using interactive demonstration methods, (2) understanding concepts through interactive demonstration methods, (3) students' interest in learning temperature and heat material, and (4) student learning activeness. In more detail, the students' responses to the interactive demonstration method can be seen in Fig. 2.

Based on the results of the student response questionnaire analysis, it is known that the percentage of students' responses using interactive demonstration methods on the subject of temperature and heat material is $82.58 \%$ classified as very strong. 


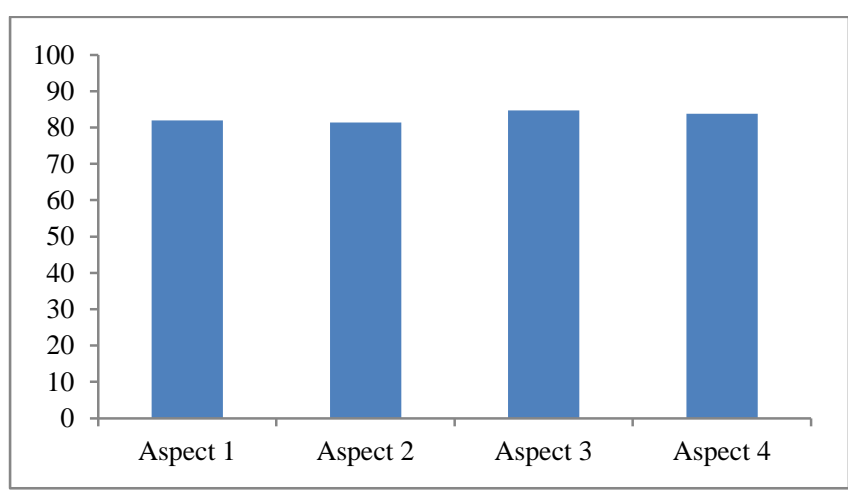

Fig. 2 Summary of Students Respons

According to the data that has been obtained from (1) mastery of learning outcomes that achieve classical completeness is $86.67 \%$, (2) student activities are classified as active during learning using interactive demonstration methods, and (3) student responses are very strong during learning using the method interactive demonstration, the use of interactive demonstration methods is classified as effective, used in the discussion of heat and calor in the tenth-grade students of the Segedong Number 1 Senior High School.

\section{B. Discussion}

According to research data analysis that has been done, it is known that the effective interactive demonstration method is used in the discussion of temperature and heat in tenth level students in high school number 1 Segedong. The use of interactive demonstration methods is effective because, from the results of the analysis of student learning outcomes data, it is known that the average student learning outcomes are 85.17, with a percentage of completeness of $86.67 \%$, so students are said to complete classically. The results are due to the activity of students during the learning process. This can be seen from observing student activities during learning. Most students pay attention to the teacher's explanation and answer the teacher's questions at the apperception stage, pay attention to the teacher's explanation and answer the teacher's questions at the motivation stage, pay attention to the teacher's explanation and answer the teacher's questions at the demonstration stage, discuss with group friends and find solutions for completion of the prediction sheet. asking questions to the teacher about material that has not been understood, and conveying opinions when concluding. This is also reinforced from the results of student questionnaire responses to the fourth aspect that measures student learning activeness. Based on student questionnaire responses to aspects it is known that students feel activated during the learning process, for example through apperception, motivation, demonstration, prediction, the conclusion. This is because the interactive demonstration method requires students to be more active in learning activities. According to Rafasah (2010), this interactive demonstration was introduced as an activity that allowed students to be more active and to be fun learning for students.

In the apperception stage, the concepts to be conveyed are related to the real world or the daily lives of students. One of them is the habit of parents who measure body temperature when they have a fever with their palms. Unlike doctors who always measure body temperature using a thermometer. According to Trianto (2009), the subject matter will add meaning if students learn the subject matter presented through the context of their lives, and find meaning in the learning process, so that learning will become more meaningful and enjoyable. This can be seen from student activities, as many as $63.07 \%$ of students are quite active. Through the motivation stage, the concept to be conveyed is also related to the previous concept of a temperature measuring device such as a thermometer. Meanwhile, temperature gauges using the palm is not a standard measuring instrument. According to Trianto (2008) students who are less able to connect between what they learn and how knowledge is applied to new situations can influence learning outcomes. By linking what they learn with how knowledge is applied to new situations can influence students. Evident from the activities of students at the motivation stage of $6.36 \%$ classified as quite active.

The next step is to pay attention to the teacher's explanation and answer the teacher's questions during the demonstration phase. At this stage, active students are $98.44 \%$. Here is the essence of the interactive demonstration method. Almost all students are directly involved in learning activities. At this stage, students are asked to consider and respond to the teacher's demonstration of the experiments relating to temperature and heat. Demonstrations relating to common events in everyday life. The demonstration then takes place interactively between the teacher and the students and between the students in the group in making predictions about the experiments that will occur.

The next step is to ask the teacher questions about material that is not yet understood. At this stage, student activity is at the smallest percentage of $35.55 \%$. Some students ask at this stage. After crosschecking with students by giving several questions related to the concept that has been conveyed, it can be seen that most students understand the concepts that have been conveyed. That is, at least students who don't ask are because students already understand the concept. The last step is to conclude. At this stage, students are assisted by the teacher to make conclusions related to the learning that has taken place. As many as $58.00 \%$ of students together with teachers conclude. Overall students respond to learning with very strong criteria for the learning method used, students are active in learning, and students understand the concept so that ultimately student learning outcomes reach the minimum mastery criteria set by the school.

\section{CONCLUSIONS}

Based on the results of data analysis, in general, can be concluded that the effectiveness of interactive demonstration methods on temperature and calor in the tenth-grade students of the Segedong Number 1 Senior High School is classified as effective. Average student learning outcomes using interactive demonstration methods on temperature and calor in the tenthgrade students of the Segedong Number 1 Senior High School reached completeness of $86.67 \%$ and is classified as complete in classical. Student learning activity when following the process of interactive demonstration method on temperature 
and calor material in the tenth grade students of the Segedong Number 1 Senior High School amounted to $67.65 \%$, classified as active. Student response when following the process of interactive demonstration method on temperature and in the tenth-grade students of the Segedong Number 1 Senior High School of $82.58 \%$ is very strong.

\section{REFERENCES}

Annisa, Fanny Nurul., Karim, Abdul., \& Aminudin, Ahmad. (2014). Penerapan Metode Pembelajaran Demonstrasi Interaktif untuk Meningkatkan Hasil Belajar Fisika Siswa SMA pada Konsep Suhu dan Kalor. Jurnal Pengajaran MIPA, 19(1), 88-93.

Rafasah. (2010). Melalui Penerapan Metode Demonstrasi Interaktif dapat Meningkatkan Hasil Belajar Konsep Suhu dan Kalor siswa Kelas X.1 pada SMA Negeri 1 Samudera. Aceh Utara: Dinas Pendidikan Pemuda dan Olahraga.

Riduan. (2010). Dasar-dasar Statistika. Bandung: Alfabeta.

Sugiyono. (2012). Metode Penelitian Kuantitatif Kualitatif dan $R \& D$. Bandung: Alfabeta.

Trianto. (2008). Mendesain Pembelajaran Kontekstual. Jakarta: Cerdas Pustaka Publisher.

Trianto. (2009). Mendesain Model Pembelajaran Inovatif Progresif : Konsep, Landasan, dan Implementasipada Kurikulum Tingkat Satuan Pendidikan (KTSP). Jakarta: Kencana Prenada Media Grup.

Wenning, Carl J. (2005). Levels of Inquiry: Hierarchies of Pedagogical Practices and Inquiry Processes. Journal of Physics Teacher Education, 2(3), 3-11. 